\title{
EDUCATIONAL VALUES OF THE MAIN CHARACTERS IN THE IMPORTANCE OF BEING EARNEST PLAY BY OSCAR WILDE
}

\author{
Lenny Solo \\ English Education Department \\ STKIP Panca Sakti Bekasi, Jawa Barat, Indonesia \\ lennysolo@panca-sakti.ac.id
}

\begin{abstract}
Educational values play important role in the human lives. These values are found in many literary works. Play is a literary works portrayed many educational values. This study aims to analyze the important of educational values portrayed and to investigate how the educational values integrated in The Importance of Being earnest play by Oscar Wilde in people education. The qualitative approach is applied this study. It studied the data in written or oral word descriptively. The primary data is taken from the script of The Importance of Being earnest play. It also uses references on literary books and some relevant materials as its secondary data to support and complete each other. This study found that The Importance of Being earnest play portrayed the following educational values: responsible, curiosity, creative, hard work, honest, and discipline. Besides, Oscar Wilde also ask the reader to become earnest in everyone in our life.
\end{abstract}

Keywords: Play, Earnest, Educational Value, Honest, Importance

\section{INTRODUCTION}

Literature is one of significant parts of a society language. The author and their literary works can't be separated because literature usually tells about human life and their society or culture which written by the author through their thinking and language. Literature can make a creative writing in describe anything and scientific work, but the type of writing is used to be works in the creative imagination. It is works of poetry, drama, fiction, and nonfiction.

Drama is a nonfiction literature (Potter, 1967). This is one of communication tool that really helps the effective learning process. When we are reading drama, we easier to remember than what can only be read or just listen. Drama could have a positive influence in education. The way drama clearly explains the process and message, so it can generate interest and motivation to learn.

In this study, the writer would like to discuss the important of education of "The Importance of Being earnest" drama which give information to the readers about the importance of education. The story is very interesting. The drama written by Wilde (1895), "The Importance of Being earnest" drama also has education value, so the readers will take lessons from this drama. Education is very important in our life, but not everybody can get education because the school. In the other side, education can make better knowledge human life in the future.

Education according to Good (1994) is the aggregate of all the processes by mean of which a person develop abilities, attitudes, and other form of behavior of positive value in the society in which he lives.

(1972) may be viewed as process for providing learners with (at least minimal) skill, knowledge, and attitudes so that they may live and produce in our society when they legally exit from our educational agencies. The "product" of education is no less than the achievement of these required minimal skills, knowledge and attitudes. The 
behavior and achievements of learners as they function as citizens determines whether the "product" has been achieved.

Value is important and lasting beliefs or ideals shared by the members of a culture about what is good or bad and desirable or undesirable. Values have major influence on a person's behavior and attitude and serve as broad guidelines in all situations (http://www.businessdictionary.com, 13 September 2014).

The truth value and universally accepted is the value that produces a behavior and behaviors that have a positive impact for people that to do this and for the other (Richard, 1997). The principle that presented above can help to achieve peace and also prevent the loss or hardship either to themselves or others.

According to Earle (1992) value is positive quality of anything it is desirable, useful, interesting, good and important; only a few of the terms available for the expression of positive values. Whether values are part of intrinsic nature of thing or simply a matter of how humans respond to thing is controversial. In sociology, values theory is concerned with personal values which are popularly held a community, and how those values might change under particular conditions. Different groups of people may hold or prioritize different kinds of values influencing social behavior.

Based on the explanation above values education implies do your own thing, operate without a moral or ethical guide, anything else. Character education should be provided in schools to establish and affirm those substantial moral principles necessary.

The traditional values do not matter and students should decide basic value questions for themselves without guidance from educators, religious leaders, or parentshas an eroding effect on the cornerstones of American society.
The Bureau advocates core ethical values, and has created a system to help children understand these values by relating them to parts of the body: positive mental attitude (mind), respect (eyes and ears), integrity (mouth), compassion (heart), cooperation (hands), perseverance (stomach or guts), and initiative (feet).

According to Kaswardi (1993) educational value is the planting and development of values in person. Educational value should not constitute a special program or lesson, such as a drawing or English lesson, but rather a dimension of the whole enterprise of education. Education does not only want to develop the knowledge, skills, technologies, but also want to develop other aspects: personality, morals, and ethics, etc., all of which can be called educational value.

Education correlates positively with achievement values. The constant grading and comparing of performance in schools, emphasizing meeting external standards, could account for this. The associations of education with values are largely linear, with the exception of universalism values.

Universalism begins to rise only in the last years of secondary school. They are substantially higher among those who attend university. This may reflect both the broadening of horizons that university education provides and a tendency for those who give high priority to universalism values to seek higher education.

Drama is a literary composition in either verse of prose, intended to be performed by actors upon the state, and usually in the form of narrative told by the action and dialogue of characters portrayed by the actors.

Drama is usually divided in to several acts which, for more effective telling of the story, are often divided in to scenes. Drama has three unites, those are: 
a) The Unity of Time

b) The Unity of Place

c) The Unity of action.

In terms of Ancient Greek Times, the principle types of the drama are:

\section{Tragedy}

The drama of tragedy deals with serious themes and concerned especially with the deeper suffering of humanity. Generally, in a tragedy the leading character is brought to an end of a calamitous nature because of some passion or weakness of his own. However, the hero of tragedy is often of admirable character end, achieves an understanding of the forces with which he has been contending and an inspiring growth of his inner self.

\section{Comedy}

The drama of comedy generally deals with the light and amusing side of life and usually has a happy ending. Comedy often deals with follies and absurdities of human beings and sometimes has a satiric purpose.

\section{Biography of the Author Oscar Wilde}

He was born on $16^{\text {th }}$ of October in 1854 in Dublin. $\mathrm{He}$ is an author, a playwright and a poet. He was a famous literary in the late of Victorian England. He was also known for his brilliant wit, his flamboyant style and his infamous imprisonment for homosexuality.

After finishing his study in Oxford University, he taught as a poet, art critic and a leading proponent of the principles of aestheticism.

In the year of 1891, he published his novel tittled "The Picture of Dorian Gray", it was reflecting as a sacrilegious by Victorian critics, but now, it is considered one of his most notable works. Oscar Wilde as a dramatist has produced many plays/drama, there are many of his plays/dramas were well accepted including his satirical comedies, such as Lady Windermere's Fan (1892), A Woman of No

Importance (1893), An Ideal Husband (1895) and The Importance of Being Earnest (1895), the most his famous play.

Oscar Wilde has an affair with a young man, so it brought him to be arrested on charges of "gross indecency" in the year of 1895. He was imprisoned for two years and died three years later in the 46 years old.

\section{The Relevance of the Study}

In this researh, the researcher present the relevance of the study that is discussed and subjected to the same work related on this research.

Some previws study are also done focusing on analysis of educationa value on movie, Aisyah (2015) has studied about "An Analysis of Educational Value of NIM's Island Movie". In this studied, she find out the educatinal value in that movie are never give up, self-confidence, friendly and be polite, love, forgiveness, optimism, help each other, and responsible. She also found the integration of educational values in NIM Island toward children education.

Another research is by Suryati (2018). She focused to find out the types of educational value in Life of Pi movie and the benefits of watchig Life of Pi movie.

Another research is Permanasari (2016)she analysed the eductional value of the novel "Nilai-nilai Pendidikan Dalam Novel Sepenggal Bulan Untukmu karya Zhaenal Fanani dan Kaitannya dengan Pembelajaran Sastra di SMA she concerned to find out the kind of educational value in the novel of Sepenggal Bulan Untukmu and the correlation betwen the educational value in that novel and the material subject of literature in the Senior High School.

The differences betwen this research and other researchs are the researcher focused on the drama, the titled of the drama is "The Importance of being earnest". The researcher focused on the educational values of the drama and how to integrate the 
educational values of seen in the The Importance of Being Earnest in people education.

\section{Literary Elements of the "The Importance of being earnest" drama}

To understand the meaning of a literary work, it is important to analyze the structure the work the literary elements of the drama The Importance of Being Earnest is as the following:

\section{Character and characterization}

Character is a figure or figures who is participate and responsible to the within story, poem, or other literature. Character is really important to the literature because there is interaction between the characters and the readers.

The characters that the author use assist in forming plot of a story.

We know what happen to the story through character, so that make the readers interest to read the stories to see how the plot work out (DiYanni, 2004).

Character may be presented mainly through description and discussion, or in a more dramatic manner, by the author's simply reporting the character's speech and action (Little, 1970). Character is a figure who is responsible to the thoughts and actions with a story, poem, or other literature. Characters are extremely important because they want which the medium through a reader interacts with a piece of literature. Every character has his or her own personality. Which a creative author uses to assist in forming the plot of a story or creating a mood.

\section{Major character}

\section{John (Jack/Earnest) Worthing}

Jack Worthing is a protagonist play in this play. He is a young man that is responsible and respectable person. He leads a double life. He has a country estate in Hertfordshire. His name is Jack in Hertfordshire and in London his name is Ernest.

When he was a baby, he was found in a handbag in the cloakroom of Victoria Station by an old man who adopted him and it made Jack guardian to his granddaughter, Cecily Cardew. Jack is falling in love with, Gwendolen Fairfax who is his friend's cousin Algernon.

\section{Algernon Moncrieff}

Algernon is a delightful, slothful, attractive bachelor, and Lady Bracknell's nephew. He is cousin of Gwendolen Fairfax, and has a best friend named Jack Worthing, whom he has known for years as Ernest.

Algernon is talented, humorous and selfish. He creates a fictional friend named "Bunbury," he is an invalid person who let Algernon go to Bunbury's country when he is suddenly sick. Algernon do that to free from unpleasant or dull social obligations

\section{Gwendolen Fairfax}

She is a daughter of Lady Bracknel cousin of Algernon. Gwendolen loves Jack, whom she knows as Ernest. She is a trendsetter of high fashion and society. Gwendolen ia a nobleman, graceful and has a good moral. She speaks well with a well manner and morality.

She is modern, intellectual, cosmopolitan, and utterly pretentious. Gwendolen wants to marry to the man named Earnest and will not marry a man without that name.

\section{Cecily Cardew}

Cecily is the granddaughter of the old man who found and adopted Jack when Jack was a baby. She is Jack's ward. She is a little woman who probably become the most realistically drawn character in the play.

Same with Gwendolen, Cecily also 
obsessed with the name Ernest. She is falling in love with a person named Earnest in her imagination and finally she found that man whose name is Earnest that is Jack's brother.

\section{Lady Bracknell}

Algernon's haughty, moneyoriented, and intimidate aunt and Gwendolen's mother. Lady Bracknell married with a good gentleman and she wants her daughter also married to the right gentleman. She has many conditions of "qualified young men" who will marry to her daughter.

\section{Minor characters}

\section{Miss Prism}

Cecily's governess. She is an endless source of pedantic bromides and clichés. She highly approves of Jack's presumed respectability and harshly criticizes his "unfortunate" brother. Also, she entertains romantic feelings for Dr. Chasuble.

\section{Rev. Canon Chasuble, D.D.}

The rector on Jack's estate. Jack and Algernon want Dr. Chasuble to change their name become "Earnest" both of them want to be christened as "Ernest." Dr. Chasuble has a secret romantic feeling for Miss Prism. The initials after his name stand for "Doctor of Divinity."

\section{Lane}

Algernon's manservant. $\mathrm{He}$ is the only person who knows Algernons' secret about "Bunburying." Lane only appears in Act I.

\section{Merriman}

The chief of servant at the Manor House, Jack's estate in the country. Merriman appears only in Acts II and III.

\section{Plot}

\section{Exposition}

Jack and Algernon are friend and they are rich gentlemen. Jack (his name in Country) lives with his ward named Cecily and take his ward in the country.

Algernon lives in elegance home in London and has created an imaginary invalid friend named Bunbury whom he visits in the country whenever he felt bored in the city.

Jack has also created an imaginary brother called Ernest whom he uses as pretext for going up to London and enjoying himself.

Jack wants to marry Gwendolen, Algy's cousin. He asks Gwendolen to marry him in Algernon's house and she accepts it because her dream is to marry someone by the name of Earnest.

Gwendolen's mother, Lady Bracknell, at first fell happy because her daughter will marry to wealthy gentleman, but after interviewing him, she found that Earnest doesn't have parents and he does not know who his parents are.

In the second act, the scene is set in Jack's country house. Algernon go to jack's country and meet Cecily. He introduces his self as Earnest to Cecily. Both of them fall in love at the first sight.

But Cecily and Gwendolen meet each other. Both of them know that they love the same man named Earnest. In feew minutes later, Jack and Algernon meet with them and explain what have been happend. After the problem is clear, Gwendolen and Cecily forgive them and they are agree to continue their relationship in one condition, jack and Algernon must be re-christened as "Earnest."

Lady Bracknell also go to Jack's country. When she arrives there, she stil forbids Gwendolen to marry Jack. There seems to be no way out of this, but Lady Bracknell unexpectedly recognizes Miss Prism, Cecily's governess: she had been her 
dead sister's governess, and had, years before, disappeared with this sister's baby. Miss Prism confesses that she had accidentally put the baby in a handbag which she had than left in Victoria station.

On hearing this, Jack, startled, leaves the room and comes back with the handbag in which he had been found as a baby. It is the same bag, Miss Prism is sure. He is the baby she lost, and since that baby was Lady Bracknell's sister's son, it turns out that Jack is her nephew, and Algernon's brother. Upon farther enquiry, moreover, it is found out that his original name was indeed Ernest. All is well, in the end, and the two couples can finally marry.

\section{Conflict}

Jack has many obstacles to his relationship with Gwendolen. One of the big obstacles is he doesn't know his parents. Besides, the other obstacle is Gwendolen's only wants to marry to the man with the name "Ernest," since she does not know Jack's real name

\section{Rising Action}

Algernon go to Jack's home and find out that jack has a double life and he has a beautiful little ward named Cecily. He suddenly falls in love with Cecily at the first sight and identify himself as Earnest, Jack's brother in London.

\section{Climax}

Gwendolen and Cecily know that both Jack and Algernon have been lying to them, both of their real named are not "Ernest."

\section{Falling Action}

Miss Prism is meet her sister's baby that has been lost for many years after hearing the expiation about the story when Jack discovered to the old man and seeing a handbag from the governess abandoned. Jack as a baby and Jack is discovered to be Algernon's elder brother, and is in actual fact named Earnest.

\section{Setting}

Time: Victorian Period, Around 1894 in Worthing, England.

Place: (a) Algernon Moncrieff's Flat in Hall-Moon Street, (b) the Garden at the Manor House, Woolton, (c) drawing-Room at the Manor House, Woolton

\section{Themes}

Victorian Social Issues: The nature of marriage; the constraints of morality; hypocrisy vs. Inventiveness, lies, fantasy, deceit \& morality, love, romance \& marriage, respectability \& social conventions, class \& wealth, gender, foolishness.

\section{METHOD}

By employing qualitative study, the writer got the data in the form of qualitative data. (Arikunto, 2010) Defines that qualitative study focuses on describing and analyzing a phenomenon, social activity, perception, belief, individual and thought. Then, the research can be categorized as library research. It is a research in which the way of collecting data taken from a variety of literatures. Literatures meant here are not only the books, but also materials taken from journal, magazines, newspaper, internet etc.

The research design in this study can be described as an arrangement condition for collecting and analyzing data which are taken from "The Importance of being earnest" Drama originally written by Wilde (1895). By using objective approach, the writer analyzed the educational values which are found in this novel.

The data of this resesarch is the form of exposure of the writing in the form of qualitative data such as statements, uttarances, iludtrations, and descriptions of educational values containrd in the data source.

To check the trustworthiness of the 
data, theoretical triangulation, credibility and dependability were used in this study.

\section{RESULT AND DISCUSSION}

Educational values are the term used to name several things, and there is much academic controversy surrounding it. Some regard it as all aspects of the process by which teacher (and other adult) transmits values to pupils (Farrel, 2009).

From "The Importance of being Earnest" drama the writer can takes some educational values there are:

1. The value of Responsible

\begin{tabular}{|l|l|}
\hline Character & \multicolumn{1}{|c|}{ Statement } \\
\hline JACK & $\begin{array}{l}\text { My dear fellow, there is nothing } \\
\text { improbable about my } \\
\text { explanation at all. In fact it's } \\
\text { perfectly ordinary. Old Mr. } \\
\text { Thomas Cardew, who adopted } \\
\text { me when I was a little boy, } \\
\text { made me in his will guardian to } \\
\text { his grand-daughter, Miss Cecily } \\
\text { Cardew. Cecily, who addresses } \\
\text { me as her uncle from motives of } \\
\text { respect that you could not } \\
\text { possibly appreciate, lives at my } \\
\text { place in the country under the } \\
\text { charge of her admirable } \\
\text { governess, Miss Prism. }\end{array}$ \\
\hline ALGERNON & $\begin{array}{l}\text { Where in that place in the } \\
\text { country, by the way? }\end{array}$ \\
\hline
\end{tabular}

From the short dialogue above, it shows that Jack is responsible to take care Cecily as his guardian.from she was child until adult.

2. The value of Curiosity

\begin{tabular}{|l|l|}
\hline \multicolumn{1}{|c|}{ Character } & \multicolumn{1}{|c|}{ Statement } \\
\hline LADY & $\begin{array}{l}\text { Pencil and note-book in hand. I } \\
\text { feel bound to tell you that you } \\
\text { are not down on my list of } \\
\text { eligible young men, although I } \\
\text { have the same list as the dear }\end{array}$ \\
& $\begin{array}{l}\text { Duchess of Bolton has. We } \\
\text { work together, in fact. } \\
\text { However, I am quite ready to }\end{array}$ \\
\hline
\end{tabular}

\begin{tabular}{|c|c|}
\hline & $\begin{array}{l}\text { enter your name, should your } \\
\text { answers be what a really } \\
\text { affectionate mother requires. } \\
\text { Do you smoke }\end{array}$ \\
\hline JACK & $\begin{array}{l}\text { Well, yes, I must admit I } \\
\text { smoke. }\end{array}$ \\
\hline $\begin{array}{l}\text { LADY } \\
\text { BRACKNELL }\end{array}$ & $\begin{array}{l}\text { I am glad to hear it. A man } \\
\text { should always have an } \\
\text { occupation of some kind. } \\
\text { There are far too many idle } \\
\text { men in London as it is. How } \\
\text { old are you? }\end{array}$ \\
\hline JACK & Twenty-nine. \\
\hline $\begin{array}{l}\text { LADY } \\
\text { BRACKNELL }\end{array}$ & $\begin{array}{l}\text { A very good age to be married } \\
\text { at. I have always been of } \\
\text { opinion that a man who desires } \\
\text { to get married should know } \\
\text { either everything or nothing. } \\
\text { Which do you know? }\end{array}$ \\
\hline JACK & $\begin{array}{l}\text { [After some hesitation.] I know } \\
\text { nothing, Lady Bracknell. }\end{array}$ \\
\hline $\begin{array}{l}\text { LADY } \\
\text { BRACKNELL }\end{array}$ & $\begin{array}{l}\text { I am pleased to hear it. I do not } \\
\text { approve of anything that } \\
\text { tampers with natural } \\
\text { ignorance. Ignorance is like a } \\
\text { delicate exotic fruit; touch it } \\
\text { and the bloom is gone. The } \\
\text { whole theory of modern } \\
\text { education is radically unsound. } \\
\text { Fortunately in England, at any } \\
\text { rate, education produces no } \\
\text { effect whatsoever. If it did, it } \\
\text { would prove a serious danger } \\
\text { to the upper classes, and } \\
\text { probably lead to acts of } \\
\text { violence in Grosvenor Square. } \\
\text { What is your income? }\end{array}$ \\
\hline JACK & $\begin{array}{l}\text { Between seven and eight } \\
\text { thousand a year. }\end{array}$ \\
\hline $\begin{array}{l}\text { LADY } \\
\text { BRACKNELL }\end{array}$ & $\begin{array}{l}\text { That is satisfactory. What } \\
\text { between the duties expected of } \\
\text { one during one's lifetime, and } \\
\text { the duties exacted from one } \\
\text { after one's death, land has } \\
\text { ceased to be either a profit or a }\end{array}$ \\
\hline
\end{tabular}




\begin{tabular}{|l|l|}
\hline & $\begin{array}{l}\text { pleasure. It gives one position, } \\
\text { and prevents one from keeping } \\
\text { it up. That's all that can be said } \\
\text { about land. }\end{array}$ \\
\hline & $\begin{array}{l}\text { I have a country house with } \\
\text { some land, of course, attached } \\
\text { to it, about fifteen hundred } \\
\text { acres, I believe; but I don't } \\
\text { depend on that for my real } \\
\text { income. In fact, as far as I can } \\
\text { make out, the poachers are the } \\
\text { only people who make } \\
\text { anything out of it. }\end{array}$ \\
\hline
\end{tabular}

The dialogue shows that lady Bracknell is very curiosity to Jack's life because she wants to know all about Jack before he gets marry to her daughter.

\section{The value of Creative}

\begin{tabular}{|l|l|}
\hline Character & \multicolumn{1}{|c|}{ Statement } \\
\hline CECILY & $\begin{array}{l}\text { I wish Uncle Jack would allow } \\
\text { that unfortunate young man, } \\
\text { his brother, to come down here } \\
\text { sometimes. We might have a } \\
\text { good influence over him, Miss } \\
\text { Prism. I am sure you certainly } \\
\text { would. You know German, } \\
\text { and geology, and things of that } \\
\text { kind influence a man very } \\
\text { much. [CECILY begins to } \\
\text { write in her diary.] }\end{array}$ \\
\hline MISS PRISM & $\begin{array}{l}\text { [Shaking her head.] I do not } \\
\text { think that even I could produce } \\
\text { any effect on a character that } \\
\text { according to his own brother's } \\
\text { admission is irretrievably weak } \\
\text { and vacillating. Indeed I am } \\
\text { not sure that I would desire to } \\
\text { reclaim him. I am not in favour } \\
\text { of this modern mania for } \\
\text { turning bad people into good } \\
\text { people at a moment's notice. } \\
\text { As a man sows so let him reap. } \\
\text { You must put away your diary, } \\
\text { Cecily. I really don't see why } \\
\text { you should keep a diary at all. }\end{array}$ \\
\hline
\end{tabular}

\begin{tabular}{|c|c|}
\hline CECILY. & $\begin{array}{l}\text { I keep a diary in order to enter } \\
\text { the wonderful secrets of my } \\
\text { life. If I didn't write them } \\
\text { down, I should probably forget } \\
\text { all about them. }\end{array}$ \\
\hline
\end{tabular}

Every single word Cecily writes about what have been happen to her life. She writes it in her small diary.

4. The value of Hard work

\begin{tabular}{|l|l|}
\hline \multicolumn{1}{|c|}{ Character } & \multicolumn{1}{|c|}{ Statement } \\
\hline JACK. & $\begin{array}{l}\text { I have a country house with } \\
\text { some land, of course, attached } \\
\text { to it, about fifteen hundred } \\
\text { acres, I believe; but I don't } \\
\text { depend on that for my real } \\
\text { income. In fact, as far as I can } \\
\text { make out, the poachers are the } \\
\text { only people who make } \\
\text { anything out of it. }\end{array}$ \\
\hline LADY & $\begin{array}{l}\text { A country house! How many } \\
\text { bedrooms? Well, that point can } \\
\text { be cleared up afterwards. You } \\
\text { have a town house, I hope? A } \\
\text { girl with a simple, unspoiled } \\
\text { nature, like Gwendolen, could } \\
\text { hardly be expected to reside in } \\
\text { the country. }\end{array}$ \\
\hline JACK. & $\begin{array}{l}\text { Well, I own a house in } \\
\text { Belgrave Square, but it is let } \\
\text { by the year to Lady Bloxham. } \\
\text { Of course, I can get it back } \\
\text { whenever I like, at six months' } \\
\text { notice }\end{array}$ \\
\hline
\end{tabular}

5. The value of Honest

\begin{tabular}{|l|l|}
\hline \multicolumn{1}{|c|}{ Character } & \multicolumn{1}{|c|}{ Statement } \\
\hline JACK & $\begin{array}{l}\text { On the contrary, Aunt } \\
\text { Augusta, I've now realised for } \\
\text { the first time in my life the } \\
\text { vital Importance of Being } \\
\text { Earnest. }\end{array}$ \\
\hline
\end{tabular}


Jack realizes that becomes an earnest person would be a grateful than others. It is very important to keep the earnestness in our heart.

6. The value of Discipline

\begin{tabular}{|l|l|}
\hline \multicolumn{1}{|c|}{ Character } & \multicolumn{1}{|c|}{ Statement } \\
\hline MISS PRISM. & $\begin{array}{l}\text { [Calling.] Cecily, Cecily! } \\
\text { Surely such a utilitarian } \\
\text { occupation as the watering of } \\
\text { flowers is rather Moulton's } \\
\text { duty than yours? Especially at } \\
\text { a moment when intellectual } \\
\text { pleasures await you. Your } \\
\text { German grammar is on the } \\
\text { table. Pray open it at page } \\
\text { fifteen. We will repeat } \\
\text { yesterday's lesson. }\end{array}$ \\
\hline
\end{tabular}

Educational values that are found in this drama are responsible, curiosity, creative, hard work, honest, and discipline. The value can be presented in educational values depend on people themselves how they define it.

The integration of educational value to people education are the major character teaches us to be ourself, always be honest to our self. The educational value of responsible, creative, hard work, and discipline teach us to become a good person in reach ambitions. And the educational value of, curiosit and honest make us become a person with a good moral $n$ morality.

\section{CONCLUSION}

There 6 educational values found in this research, they are (1) responsible, (2) curiosity, (3) creative, (4) hard work, (5) honest, and (6) discipline.

All the educational values found from this drama have a good integration to people education, because it teaches people many positive things such as become an honest man and always say the truth are the important things to become a good person and have a good moral n morality.

\section{REFERENCES}

Aisah, S. (2015). An Analysis of Educational Values of "NIM'S Island" Movie. Graduate Thesis, IAIN Salatiga, Salatiga.

Arikunto, S. (2010). Prosedur Penelitian Suatu Pendekatan Praktik. Jakarta : Rineka Cipta.

DiYanni, R. (2004). Literature Approaches to Fiction, Poetry, and Drama. . New York: Mc Graw Hill.

Earle, W. J. (1992). Introduction to Philosophy. Singapore:Mc Graw-Hill Inc. Singapore: Mc Graw-Hill Inc.

Farrel, M. (2009). Foundations of Special Education An Introduction. USA: Wiley-Blackwell Publishing.

Good, C. V. (1994). In I. Djumberansjah, Filsafat Pendidikan. Surabaya: Karya Abditama.

http://www.businessdictionary.com.

September 2014). definition values.html, retrieved 10.32). retrieved 10.32).

Kaswardi. (1993). Pendidikan Nilai Memasuki Tahun 2000. Jakarta: Grasindo.

Kaufman, R. A. (1972). Educational System Planning. USA: Prentice Hall Inc.

Little, G. (1970). Approach to Literature, An Introduction to Critical Study of Content and Method in Writing. Australia: Science Press.

Permanasari, I. (2016). Nilai-nilai Pendidikan dalam Novel Sepenggal Bulan Untukmu Karya Zhaenal Fanani dan Kaitannya dengan Pembelajaran Sastra di SMA. Graduate Thesis, Universitas Lampung, Pendidikan Bahasa dan Sastra Indonesia, Lampung.

Potter, J. L. (1967). Elements of Literature. USA: The Odyssey Press, Inc.

Richard, L. E. (1997). Mengajarkan Nilai-Nilai Kepada Anak. Jakarta: Gramedia.

Suryati, S. D. (2018). An Analysis of Educational Values in "Life of Pi" Movie. Graduate Thesis, Raden Intan State Islamic University, English Department, Lampung.

Wilde, O. (1895). The Importance of being 
Dialectical Literature and Education Journal (DLEJ) Volume 5, Issue 1, June 2020

Earnest. The Pennsylvania State University. Pennsylvania: The
p-ISSN 2548-6926, e-ISSN 2714-996X

https://dlejpancasakti.ac.id/index.php/dlejpancasakti

Pennsylvania State University. 